\title{
The Problems Existing in the Design of College English Micro Class and Some Relevant Suggestions
}

\author{
Li Dan \\ Liaoning Institute of Science and Technology, Benxi, China
}

Keywords: Micro course; design; student-centered; teaching strategy

\begin{abstract}
The traditional teaching method in universities needs to be transformed in technology so as to drawing students' attention. Fundamental changes have taken place in teaching mode and teaching method when micro course is applied in college English teaching. As a new media mode, micro-course is very popular in college English teaching because of its advantages. The paper demonstrates the advantages of micro courses. And it also reveals some problems of micro course designs of college English teachers. Some problems are mainly reflected in the lack of understanding of the nature, orientation and function of micro courses. Technical and design issues of micro-course development also need concerning. And some suggestions for micro course design are also discussed. Micro course is really important means to realize the flipped classroom teaching model. The main emphasis is to design micro course in accordance with teaching content so students can further focus on their autonomic learning. Compared with the traditional teaching methods, the micro course provided new requirements for the teacher on their professional and technological aspects .Teachers should adapt modern technology and design suitable teaching micro courses.
\end{abstract}

\section{Introduction}

"College English teaching requirements" clearly states: "colleges and universities should make full use of modern information technology, adopt English teaching mode based on computer and classroom, and improve the single teaching mode dominated by teacher teaching. Teaching reform is to achieve the purpose of the transformation of teaching pattern, from the traditional of 'teachers as the center cramming teaching' to 'the students as the center the active autonomous learning mode'. Through a small video of micro courses, teachers implement to maximize the value of information resources, improve students' interest and enthusiasm to learn English in the truly sense, exert their actively subjective initiative, improve students listening, speaking, reading, writing and translating English using ability, finally to cultivate applicable talents adapted to the real society.

In the reform and development of college English teaching, micro courses teaching promotes college English classroom teaching effect and forms a new English teaching mode. All the colleges and universities are eager to make use of the new teaching theories and explore the new teaching mode, so as to apply micro course teaching to the practice of college English teaching reform. Micro course, a new teaching organization model has been paid much attention by education workers and school administrators and has become a hot topic in the field of education. Finally, micro course has been applied into actual teaching. Various teaching organizations are also carrying out various competitions in the mode of micro-class to attract more teachers to carry out micro-class teaching exploration. Since 2012, various micro-course competitions have been gradually developed in colleges and universities and cities at all levels. There are more and more micro-course competitions, micro-course design, micro-course promotion and websites related micro-course, which have played a positive role in the further development of micro-course in China.[1]

\section{Micro-Course is Very Popular in College English Teaching}

\subsection{Micro classes can be taught interactively in the network environment}

This is very different from the traditional teaching mode because the traditional teaching mode is linear and now the network teaching mode is multi-faceted. The Internet can convey a large amount of 
knowledge of English to students through pictures, sounds and video, etc. Students can also timely feedback their acceptance of knowledge and learning results, which can be effectively guided and controlled by teachers. And the study of English as a language itself is for its application in life and the communication.

\subsection{Micro class subverts the traditional teaching mode}

Micro class builds a teaching system adapted to mobility of the Internet. Micro Learning Resource refers to a structured digital Resource that uses information technology to present fragmented Learning content, process and expanded material in accordance with the law of cognition. Core content is the classroom teaching video design.

\subsection{Micro class is the reform and innovation of teaching practice itself}

The application effect of micro-class in college English teaching is very remarkable, which not only helps students to carry out autonomous learning and personalized learning, but also can effectively mobilize students' enthusiasm and initiative in the learning process, truly realizing the comprehensive improvement of college English teaching effect and teaching quality.

\subsection{Micro class is highly operable}

According to different demands of teaching, micro-lessons can be classified in different ways. Professor Hu Tiesheng explained the classification of micro class in his research results. He divided micro lessons into several categories according to teaching methods, teaching content nature, best delivery methods, main recording methods of micro-video, using objects and main functions. For example, according to the teaching method, it can be divided into experiment class, discussion class, problem class, inquiry study class, practice class and so on. According to the best transmission mode it can be divided into solution type, activity type, teaching type, etc. According to recording method, it can be divided into film type, screen type and mixed type. Teachers must make different designs according to different demands. Although micro-class is small, it reflects teachers' teaching philosophy and design thinking.[2]

\section{There are Still Some Problems in the Development and Design of College English Micro Course}

\subsection{Problems in understanding the development of micro class}

The lack of understanding of the development of micro courses is mainly reflected in the lack of understanding of the nature, orientation and function of micro courses. Teachers generally have great enthusiasm for the development of micro-lessons, but their understanding is not correct. The essence of micro class is short and concise video, which can be the explanation of knowledge points or the video slices of real class. The essence of micro class is the explanation or supplement of key points, difficulties and core contents in class. The essence of micro course is a new means to spread education resources by virtue of modern information education technology. It is the product of the development of network and information technology and education technology. This nature determines that the micro class cannot exist independently in real teaching. Combined with a flip class it can be used in practical teaching. That is to say, the application of micro class essentially depends on the teacher and the existence of subject entity class still. Some teachers consider that micro courses only increase students' interest and they didn't see it for the role of language knowledge. Only with a profound and correct understanding of the orientation and function of micro classes can teachers further do a good job in design, effectively complete the role of flipped classroom and improve teaching effect .It is also possible for students to realize the supplementary role of micro classes, better integrate into the classroom and independent learning, and achieve effective language output.

\subsection{Knowledge is so fragmented that it neglects to guide students to think about problems}

In terms of the application of micro-course, it is mainly competition oriented, ignoring the practical application of micro-course, the systematic planning of course and the needs of students. It can't promote the effective and sustainable development of language micro class. As knowledge is fragmented in the process of knowledge teaching, teachers can hardly use scattered time to help students to focus on the 
absorption of knowledge, and their behaviors of knowledge fragmentation will inevitably lead to fragmented teaching. The teaching of micro courses is limited to form. If teachers do not reasonably select teaching contents, set clear teaching objectives and carefully design teaching contents, micro courses will be no different from the traditional network teaching and will lose its value.

\subsection{Technical and design issues of micro-course development}

Teachers also have problems in the design of micro-course teaching. For example, many teachers still do not know or know very well about the technical means of micro-course development (such as camtasia and other video software+powerpoin, tpowtoon, prezi, focusky and other technical means), or the technical methods of micro-course development through live recording. As a physical classroom supplementary lessons, sharing, communication and reuse, in addition to the micro video class resources, micro package should also include teaching topic related teaching design, material, courseware and its source file, teaching reflection and practice tests and student feedback, teachers' comments on auxiliary teaching resources, etc. The design of college English micro courses should start with teaching resources and advocate diversified and flexible using methods. That is to say, micro courses are not used as the indoctrination of certain knowledge points, but should be used flexibly and flexibly. Many micro classes are too big and have no teaching focus, difficulties or doubts. Teachers select teaching content too dominant without further explanation, or organize teaching activity without any of real substance. Students learn nothing after watching video. Some teachers use a micro to implement multiple teaching goal. Knowledge density is high and as a result, many students often can't catch the key.

\subsection{Problems of digitization of knowledge evaluation}

Micro class is an auxiliary way to realize students' autonomous learning and flipped classroom. Independent learning ability is a learning behavior of students' self-management, self-planning and selfevaluation of learning and whether flipped classroom can be implemented smoothly. Students' independent learning ability is a key factor. Many flipped classrooms fail to achieve the desired effect, in large part because students do not learn micro courses on their own at the request of the teacher before class, which results in the inability of students to carry out discussions in class. According to the survey, some students said they have no way to insist on autonomous learning, the single biggest reason, however, is that they have no motivation. As a result, many students give up study, even of students with autonomous learning self-consciousness can't finish it on time. As the direct communication between teachers and students decreases, the communication between teachers and students can only be conducted through the mutual communication of network. Students' evaluation shows through data, while teachers also evaluate students' communication through data, which makes the evaluation system more simple and fails to show students' comprehensive quality. Originally the relationship between teachers and students is mainly through the classroom interaction to achieve but in the process of reform of micro course and through the network emotional interconnection between students with teachers face to face is zero. The traditional relationship between teachers and students encounters a lot of challenges in the process and there is a tendency of relationship decreasing between the between teachers and students as a whole. English is a subject that depends on teachers' detailed guidance. Excessive desertification will lead to a decline in students' interest in learning.[3]

\section{Suggestions on the Application of Micro Courses in College English Teaching}

\subsection{Teachers should be aware of the design concept of micro class in college English teaching}

The teaching design is according to the course standard request and the teaching object's characteristic. Teachers will arrange the teaching various elements orderly and decide the suitable teaching plan. Teaching design involves many aspects, such as topic selection, specific content selection, teaching method, time allocation of each content link, etc. Concerning of teaching design, John Dewey, a famous American philosopher and educator, first put forward the idea of establishing a special "linking or bridging subject", which connected learning theory with teaching practice. The core content of video of Micro course contains the teaching topic related teaching design, material courseware, teaching reflection 
and practice test and students feedback. In language teaching, teachers cannot exhaust the research on the cognitive and emotional factors of each language learner, but the common phenomenon existing in each person is conducive to the language teaching of teachers. Teachers should deeply study the cognitive and emotional factors of each individual, so as to realize the concept of "full learner" of the overall language teaching concept. Under this concept, the development and application of college English micro courses must be combined with actual classroom teaching, because only in the classroom where teachers and students interact can teachers maximize the perception of students' actual learning.

\subsection{Teachers should understand the design principles of micro-class in college English teaching}

The main parts of micro-course mainly include teaching design, media design and usability design. Within the framework of the class, the teaching design should focus on the basic characteristics of micro class, based on the learner's ability, the demand analysis, combined with the teaching goal and the function of micro class, and using the appropriate multimedia auxiliary means (such as multimedia technology, network technology, etc.), reasonable arrangement, teaching content, to make it conform to the theory " In a relatively short period of time, teachers use the most appropriate teaching methods and explain to students through a knowledge strategy, let them learning fully grasp and understand the knowledge of a valuable according to their own in the shortest possible time."

\subsection{Teachers should develop and apply micro-lessons in accordance with teaching objectives}

Teachers should first do well in selection of micro-course resources before class. According to the teaching objectives, teachers can choose or make 2-3 micro video before class. Each micro video only needs to contain a certain knowledge point or present a certain knowledge case to students. It is suggested that English teachers make their video resources. The advantage lies in the production of micro video should not only reflect the teachers' teaching idea, teaching goal, but also for different class differences in students' English level, making multiple versions, a variety of content of video resources, in order to truly achieve for students according to their aptitude. At the same time, the interactivity, length and visual effect of English teaching micro-video have an important influence on the quality of classroom teaching. In the general English stage, the curriculum is mainly designed to improve the five basic skills of listening, speaking, reading, writing and translating. In the setting of micro-course content, teachers can skillfully integrate these five basic skills into the corresponding teaching. The micro course is only set for a certain task or a certain knowledge point. For example, in the micro writing class, the teacher had better be able to show the structure of the article through some simple dynamic schematic diagram, and list some commonly used opening and closing sentences, as well as some conjunction phrases.[4]

\subsection{Teachers should select appropriate teaching strategies for college English micro courses according to students' needs}

Because the students' English level is different, the needs of the major and the needs of the students are different; therefore, the teaching strategies adopted in micro-class teaching should be different. People's attention can only last about 20 minutes, so the duration of a micro class is generally limited to 10 minutes, with 7 minutes as the best effect. Lectures can be in the form of flash, animation, video, or PPT plus lecture, so that students can use the Internet to study the course modules at any time. In the microcourse teaching of the listening course, video and imitation modules can be properly embedded, so that students can keep their enthusiasm and interest in learning continuously and effectively. In the strategy selection of micro-course teaching, attention should be paid to the appropriate time, rich and refined subject matter, ingenious conception, which can fully attract students' attention and effectively improve students' learning initiative and autonomy.

\subsection{First students shall study and then teachers shall give emotional evaluation}

To ensure the effective application of micro-course teaching resources, teachers should upload the made or selected micro-video to the campus network platform, or directly to students, so that students can carry out learning activities before class. On the one hand, teachers should make clear the tasks of preclass learning, help students fully understand the learning content and learning objectives of this course, require students to carefully study micro-video content, and encourage competent students to continue the extended learning. At the same time, students are required to summarize their knowledge and existing 
problems after micro-video learning and timely feedback the problems to the teacher so that the teacher can carry out targeted and critical explanation in class according to these problems. It is a little more complicated than the traditional teaching evaluation, due to the fact that the small class teaching is based on the network teaching mode, the intervention of the network environment is not conducive to teacher to student's monitoring. With effective teaching models and strategies, students' ability to use English can be effectively improved. Evaluation and feedback is also one of the key links of college English micro course teaching. At the same time, as the evaluation feedback is a comprehensive evaluation of students' learning attitude and learning situation, the evaluation results should focus on motivation and praise, and teachers should attach importance to the principle of timeliness and fairness of the evaluation process.[5]

\section{Conclusion}

With the further improvement of science and technology, the practical effect of micro course in the practical application of college English will be better and better. However, teachers can't work alone and alone when they use micro classes to carry out teaching. The design, production and application of micro course will depend more on the collaboration of the team, the intercross and integration of disciplines. In the information age, co-construction and sharing of resources is an inevitable trend. We should build micro course resource library. In this way, it can not only guarantee the sharing of high-quality teaching resources, but also promote the communication and professional development of teachers, providing an opportunity for building a high-level team of teachers.

\section{Acknowledgment}

"Construction and implementation of college English graded teaching course system” Liaoning University of Science and Technology, 2016, the first batch of transformation teaching reform project sub-project

\section{References}

[1]. Li Bing, Wang Ping, "The "flipped classroom" of college English is based on micro-lectures" [J].Modern communication, 2016, (13): 11-12.

[2]. Hu Tiesheng, "Micro class: a new trend of development of regional education information resources" [J]. Electrochemical Education study, 2011, (10): 61-65.

[3]. Chen Huanhuan, “How to do well in micro lecture teaching in English teaching," [J]. Journal of Kaifeng education college, 2014 (12): 159.

[4]. LiuYanping, "Application research of micro courses in higher vocational English teaching reform," [J]. Vocational education, 2015 (9): 2067.

[5]. Lliang Wen, “Application and thinking of micro lecture environment in college English teaching,” [J]. Heilongjiang Higher education research,2016(2):163. 